\title{
US Trade and Exchange Rate Volatility: A Real Sectoral Bilateral Analysis
}

\author{
Joseph P. Byrne ${ }^{a}$, Julia Darby ${ }^{b}$ and Ronald MacDonald ${ }^{a}$ \\ ${ }^{a}$ University of Glasgow, Glasgow, United Kingdom \\ ${ }^{b}$ University of Strathclyde, Glasgow, United Kingdom
}

2nd October 2006

\begin{abstract}
In this paper we consider the impact of exchange rate volatility on the volume of bilateral US trade (both exports and imports) using sectoral data. Amongst the novelties in our approach are the use of sectoral industrial price indices, rather than an aggregate price index, and the construction of the sectoral groupings, which is based on economic and econometric criteria. We find that separating trade into differentiated goods and homogeneous goods results in the most appropriate sectoral division, and we also report evidence to suggest that exchange rate volatility has a robust and significantly negative effect across sectors, although it is strongest for exports of differentiated goods.
\end{abstract}

JEL Classification Numbers: F3.

Keywords: Sectoral Trade, Exchange Rate Volatility, Panel Heterogeneity. 


\section{Introduction}

It is often argued, since at least Ethier (1973), that exchange rate volatility should have a negative impact on international trade. This work is predicated on the assumption that firms are risk averse and exchange rate risk reduces the benefits of international trade. The existence of financial markets allows agents to hedge exchange rate risk and this may reduce or eliminate the potentially negative effect of exchange rate volatility on trade. However, forward markets are not complete, or fully utilised, (see Dominguez and Tesar, 2001), and indeed some theoretical papers have suggested that the basic effect of exchange rate volatility on trade is unchanged even with complete capital markets (see Demers, 1991).

Rose (2000) notes that empirical research on the link between exchange rate volatility and trade had essentially ceased towards the end of the 1990s. However, with analytical developments and improvements in the quantity and quality of data, there has recently been a re-examination of this issue (see, for example, Peridy, 2003; Broda and Romalis, 2004; Clark et al., 2004; Tenreyro, 2004; and Klein and Shambaugh, 2004). Because there may be differences in the impact of exchange rate volatility across sectors, recent studies have often used sectoral trade data and sought economic justifications for differences across industry. For example, Rauch (1999) develops a justification for different disaggregate trade behaviour based on the business networks involved in international trade and incomplete information.

In particular, Rauch (1999) emphasizes the importance of search costs involved in matching buyers and sellers for differentiated goods: trade of this kind is facilitated by knowledge of particular markets or networks since the characteristics of some manufactured products are not readily known (e.g. performance and reliability). Given these search costs this also means that it is not easy for firms to switch foreign suppliers or find new buyers in response to changes in the exchange rate. This will consequently affect profitability, with negative effects in instances where individuals dislike increased risk. In contrast, homogeneous, or intermediate, goods are typically traded on exchanges, product characteristics do not vary between suppliers, can be substituted quickly and are therefore not regarded as having search costs. There will be considerable indifference between homogeneous goods sourced from different suppliers.

However, existing studies of the effect of exchange rate volatility on detailed sectoral and bilateral trade, use the CPI as the price deflator for trade. Such a deflator is likely to be inappropriate at the individual sectoral level since it abstracts from the sharply differing sectoral price trends (e.g. in agriculture and in computers). In this paper we follow a number of general international trade studies 
(see for example Head and Mayer, 2000; Erkel-Rousee and Mirza, 2002; and Saito, 2004) and use price series at the industrial level as our deflator in our trade / exchange rate volatility relationships. Importantly, these general studies do not condition on exchange rate volatility.

A further novelty in our work is that we propose using economic and econometric criteria to underpin our sectoral disaggregation, while revisiting the effects of exchange rate volatility on international trade. In particular, we implement Rauch's approach to disaggregation in examining the impact of the second moment of the exchange rate on imports and exports. Furthermore, in our econometric modelling of the trade relationships we consider issues of measurement error associated with exchange rate volatility and also the endogeneity of trade and volatility, as suggested by Hau (2002), Broda and Romalis (2004) and Tenreyro (2004). Both of these econometric issues can be dealt with using instrumental variables and that is the approach we follow here. In our estimation we fully utilise a large cross sectional data set by adopting a fixed-effects panel approach, which allows us to test for cross sectional parameter heterogeneity.

The remainder of the paper is laid out as follows. Section 2 provides a brief literature review, Section 3 discusses our modelling methods, Section 4 sets out the data, Section 5 contains our results and Section 6 concludes.

\section{Issues in the Literature}

In this section we present a brief overview of some related work. In particular, we overview other studies which examine the trade-volatility relationship and then go on to review issues relating to the appropriate price deflator and the measurement of exchange rate volatility.

\subsection{Volatility and Trade}

One of the earliest empirical studies of the relationship between trade and exchange rate volatility is that of Hooper and Kohlhagen (1978), who find limited evidence from the impact of volatility on bilateral trade prices and no evidence on bilateral trade volumes. ${ }^{1}$ Bini-Smaghi (1991) argues that sectoral studies may have greater potential since they do not constrain income and price elasticities to be equal across sectors as in aggregate studies. There have been a relatively small number

\footnotetext{
${ }^{1}$ For a survey of exchange rate volatility and trade more generally see McKenzie (1999).
} 
[Table 1 Here]

of recent papers that empirically test the impact of exchange rate volatility on trade using sectoral disaggregate data and these are summarised in Table 1. As we shall see, the sectoral studies that have been conducted have not been especially supportive of a negative relationship between trade and exchange rate uncertainty and this may be attributable to the relatively small samples used and poor price proxies employed. The only general conclusion that would seem to result from this literature is that differences do exist across sectors.

Sectoral studies of trade and exchange rate volatility include Klein (1990), Belanger, Gutierrez, Racette and Raynauld (1992), and de Vita and Abbott (2004). Klein (1990), for example, comprehensively tests the impact of exchange rate uncertainty on US monthly bilateral sectoral exports to six major industrial countries for nine industries. The value of exports is used since it is suggested there are no sectoral-bilateral export prices such that we could consequently obtain sectoral-bilateral trade volumes. Klein (1990) generally finds that uncertainty has a positive effect on the value of trade. Belanger et al. (1992) considers the impact of nominal exchange rate uncertainty on real sectoral US imports from Canada for five sectors, where they deflate the value of imports by unit values. However, using unit value indexes may be problematic since there is no account taken of the quality of exports. Their overall conclusion is that exchange rate variability does not significantly depress the volume of trade.

The evidence for the UK is also not particularly indicative of a clear-cut significant effect from exchange rate volatility to the volume of trade. For example, de Vita and Abbott (2004) consider the impact of exchange rate volatility on UK aggregate exports to individual EU countries and a multilateral study of five sectors' exports to the other EU countries. Making a distinction between short- and long-run uncertainty, they show there is no evidence of an impact from short-run uncertainty, although there is evidence of an impact from long-run volatility. ${ }^{2}$

Recent sectoral studies such as those of Peridy (2003), Broda and Romalis (2004) and Clark, Tamirisia, Wei, Sadikov and Zeng (2004) find little significant evidence of a relationship between measures of exchange rate volatility and trade. Broda and Romalis (2004) conduct a bilateral sectoral study and are particularly concerned with the extent of reverse causality (i.e. they do not assume that exchange rate

\footnotetext{
${ }^{2}$ It can be argued that short run uncertainty is not important since trade can be hedged. This assumes firms always make the most of available financial instruments. For papers which discuss evidence less than fully consistent with this hypothesis see Wei (1999) and Dominguez and Tesar (2001).
} 
volatility is driven by exogenous shocks). They use data separated into "differentiated" and "commodity" trade following Rauch (1999). Exchange rate risk is assumed to have no affect on commodities - since these are obtained from organised exchanges - but may have an affect on differentiated goods since they involve expensive search costs. Trade stabilises volatility because the baskets of goods used to construct price indices of proximate countries are similar. ${ }^{3}$ The large effect of exchange rate volatility on trade is greatly reduced once the authors take account of reverse causality.

Clark et al. (2004), as part of their comprehensive study on trade and volatility, use disaggregate data divided into homogeneous and differentiated goods. They adopt a gravity framework and find evidence that there is a significant effect of exchange rate volatility on differentiated goods: if volatility is increased by one standard deviation around its mean, trade is reduced by $7-9 \%$. Although this result is not robust to time effects, the authors believe these may actually model the volatility effects themselves since they are time specific. Clark et al. use aggregate US CPI to obtain trade volumes, the merits of which we discuss further below.

Peridy (2003) can be viewed as our point of departure since his is a sectoral multilateral study of G7 exports. Emphasis is placed on avoiding sectoral and geographical aggregation bias (something explicitly tested for in our model). Peridy substitutes out domestic sectoral prices using supply variables and his results depend on the industry covered and the exporters location. Results suggest a consistently negative, if not significant, effect from exchange rate volatility, although crude materials are more sensitive than manufactured goods to the exchange rate. In a recommendation for future research, Peridy (2003) suggests each bilateral relationship should be tested, an approach we adopt below.

Recently, Tenreyro (2004) adopts a similar approach to Rose $(2000)^{4}$ by using gravity equations for aggregate country data and considers the impact of uncertainty on trade. She reports evidence of a negative effect from intra-year volatility on trade. However once instrumental variables are used this effect all but disappears, which suggests there is a substantial endogeneity issue in the sample of countries that she uses.

In sum the extant studies on the exchange rate volatility trade relationship are not particularly supportive of a clear-cut relationship. This may be attributable to the relatively small samples which have been used and the poor price proxies employed. By using better measures of the price deflators, new sectoral

\footnotetext{
${ }^{3}$ The authors invoke the empirical results from Hau (2002) who suggests that more open economies have faster pass through from exchange rate changes to the domestic aggregate price level.

${ }^{4}$ Rose (2000) finds a $13 \%$ reduction in trade from a one standard deviation increase in exchange rate volatility.
} 
definitions and larger samples we hope to provide sharper evidence on the trade exchange rate volatility link.

\subsection{Bilateral Sectoral Import Demand Studies and Sectoral Prices}

There have been a number of improvements made in the quality of data used in recent trade studies based on the volume of real bilateral sectoral imports. A difficulty previous studies have faced has been the absence of bilateral import prices. As mentioned above, researchers have used as a proxy the US CPI as a deflator for all trade, irrespective of source or destination (as in Clark et al., 2004). But the use of such a proxy will result, for example, in the same deflator being used for agricultural (homogeneous) and office (differentiated) goods, despite the fact that these series are likely to have sharply differing sectoral price trends. Studies that examine bilateral sectoral trade utilising sectoral prices instead of country aggregates or the US CPI include Head and Mayer (2000), Erkel-Rousse and Mirza (2002) and Saito (2004) who use the value added deflator, producer prices and wage levels, respectively. Importantly, these studies do not condition on exchange rate volatility. In this paper, we choose to use sectoral value added deflators to obtain our measures of import volumes. We believe this is likely to be a superior measure because it should be a good proxy of the price of traded goods whilst taking account of different sectoral trends. Also, to the extent that previous studies have not used relative prices they may suffer from an omitted variables bias. We consider the impact of relative prices in the analysis in this paper.

\subsection{Measures of Exchange Rate Uncertainty}

There are a number of possible ways to measure exchange rate volatility, including, moving average standard deviations, ARCH- based measures and higher frequency standard deviations. Baum's et al. (2004) main contribution relates to how uncertainty is modelled and they note that GARCH measures are model dependent and a moving window conflates uncertainty over time periods. They consequently utilise information at a higher frequency to construct a measure of uncertainty at a lower frequency. We use the standard deviation of monthly exchange rate changes to obtain an annual uncertainty measure. Consequently we are not conflating volatility across time periods and our measure is not based on a particular model parameterisation. 


\section{Modelling Issues}

In this section we consider some aspects related to the modelling of the trade / exchange rate uncertainty relationship. In particular, we briefly sketch the Armington approach to modelling trade relationships, then we go on to outline our econometric methods and our choice of sectoral disaggregation.

\subsection{Theoretical Model}

We take an Armington (1969) approach to the estimation of trade relations, and we estimate both price and output elasticities. The Armington model assumes separable consumer utility for goods in an industry from consumption of other products. We assume a constant elasticity of substitution (CES) utility function, where utility is derived from domestic and foreign goods,

$$
U=\left[\gamma Z^{(\theta-1) / \theta}+(1-\gamma) D^{(\theta-1) / \theta}\right]^{\theta /(\theta-1)}
$$

where $\theta$ is the constant elasticity of substitution between the domestic and traded goods, $Z$ is the trade volume which in our work is either exports, $X$, or imports, $M$, of imported goods and $D$ is the volume of domestic goods.

The first order condition from equation (1) is:

$$
\frac{Z}{D}=\left[\left(\frac{\gamma}{1-\gamma}\right) \frac{P^{Z}}{P^{D}}\right]^{\theta},
$$

where $P^{Z}$ and $P^{D}$ are trade and domestic prices, respectively. Re-writing (2) in logarithmic form, we have:

$$
\ln \left[\frac{Z}{D}\right]=\theta \ln \left[\frac{\gamma}{1-\gamma}\right]+\theta \ln \left[\frac{P^{Z}}{P^{D}}\right],
$$

This relation has been empirically implemented for multilateral industry data by, inter alia, Shiells, Stern and Deardorff (1986) who suggest elasticities are unlikely to be equal across sectors. This is also the approach of Saito (2004). A simplified form of the level relationship based on bilateral industry data is as follows:

$$
\ln Z_{i j t}=\alpha_{i j 0}+\beta_{1, i j} \ln R P_{i j t}+\beta_{2, i j} \ln D_{i . t}+e_{i j t},
$$

where $Z_{i j t}$ denotes trade from country $j$ for industry $i, D_{i . t}$ is domestic output for industry $i$ and $\ln R P_{. j}=\ln P_{. j}^{Z}-\ln P_{. .}^{D}$.

We also incorporate an exchange rate volatility term $\left(V O L_{. j}\right)$, based on risk aversion arguments, into our preferred specification. Ethier (1973) emphasizes that the exchange rate is the main source of profit risk 
for a risk averse firm. Demers (1991) suggests that even with risk neutral firms a negative association between trade and volatility can be generated. For example, if trade is dependent upon irreversible investment increased uncertainty will lead to a delay in increasing output capacity and hence trade. ${ }^{5}$ Consequently our static relationship becomes

$$
\ln Z_{i j t}=\alpha_{i j 0}+\beta_{1, i j} \ln R P_{i j t}+\beta_{2, i j} \ln D_{i . t}+\beta_{3, i j} V O L_{. j t}+e_{i j t}
$$

where $\beta_{1}$ is the price elasticity of substitution. Equation (5) can be estimated within a panel framework, which facilitates testing the equivalence of coefficients across industries: $\beta_{k, i j}=\beta_{k, i j}, \forall i$. Indeed, in a panel context we can also combine trade from a number of countries and all industries into our basic specification: $\beta_{k, i j}=\beta_{k, i j}, \forall i, j$. Additionally, we divide goods into differentiated/homogeneous products and we discuss this below and as noted previously we also compare the effect of exchange rate volatility on imports and exports. Since exports may be considered closer to the producing firm, exchange rate volatility may have a different effect.

\subsection{Econometric Methods}

In this paper we use a fixed-effects estimator to test our major hypothesis. As suggested above, we impose equivalent coefficients on the levels of the variables. Levels relationships are more likely to be homogeneous across cross sections where there are strong theoretical priors. Within the fixed-effects framework it is possible to test the equivalence of cross sectional coefficients using a Hausman type test. If the estimated coefficients in equation (5) are not equivalent, but are mistakenly restricted to be so, this may result in biased estimated coefficients. ${ }^{6}$

Pagan (1984) argues that instrumental variables are a necessary means of dealing with generated regressors when modeling risk and uncertainty. The trade and uncertainty literature has also found IV useful since there is some concern with, in particular, Hau's (2002) finding of openness reducing exchange rate volatility. Rose (2000) finds evidence that monetary arrangements can have an important bearing on trade equations estimated using panel methods. However, since the European countries considered in this paper did not participate in any formal exchange rate arrangements with the US during our sample period (1989 to 2001) we do not regard this as an issue here. Clark et al. also consider two methods of IV, with one based on the Frankel and Wei (1993) measure of long run volatility of relative money supplies. We are not convinced

\footnotetext{
${ }^{5}$ We also consider the impact of oil price volatility.

${ }^{6}$ See Pesaran and Smith (1995) for a discussion on the effect of heterogeneity in panel estimation.
} 
economic fundamentals can instrument exchange rate changes at a one month horizon, and in any case doing so would extract much of the noise in foreign exchange markets, which can be costly to a firm engaged in trade. This issue seems to be related to permanent and temporary volatility. For example, Savvides (1992) suggests unanticipated volatility has a stronger negative effect on trade flows than does anticipated volatility. By running a regression of volatility on openness, terms of trade and productivity shocks, Savvides extracts the unanticipated or temporary component. Bini-Smaghi (1991) also highlights how unexpected volatility seems to have a greater effect on trade. Therefore, papers which utilize an IV estimator and find no effect on trade may potentially be considering the impact of the expected or permanent component of uncertainty on trade.

Consequently, we adopt fixed-effects estimation and allow for both cross sectional and period effects. We adopt a method of instrumental variable estimation, by taking the fitted values from an $A R(n)$ regression of exchange rate volatility and incorporate the fitted values into our basic trade specification (equation 5).

\subsection{Sectoral Heterogeneity}

As mentioned above, Bini-Smaghi (1991) suggests that there may be different import demand and price elasticities across countries/sectors and this may be a reason why aggregate studies have found little evidence of the affect of exchange rate volatility on trade. Peridy (2003), for example, finds evidence of a different effect from exchange rate volatility across sectors. Rauch (1999) provides a theoretical justification for differences based on differentiated and homogeneous goods, due to supply networks. We suggest final durable, non-durable goods and investment goods are a good proxy for differentiated goods and we regard intermediate goods as a good proxy for homogeneous goods. Our differentiation is based on those of the UK National Statistics agency. ${ }^{7}$

\footnotetext{
${ }^{7}$ Table A1 in the Appendix provides further details on the sectoral disaggregation. We further tested for other potential groupings of industrial sectors, based on skills and technology. However, these approaches were not fruitful.
} 
[Table 2 Here]

\section{Data}

The data used in this study are from three main sources. The value of US imports, in US Dollars, is originally from the UN database COMTRADE. This is converted from product categories (SITC) to industrial sectors (ISIC) by HWWA. Additionally, we utilise exports from our sample of European countries to the US. We also use the Groningen, Growth and Development Centre database (also adopting a ISIC classification) to obtain sectoral value added and value added deflators. ${ }^{8}$ The data appendix provides more details. We utilise annual data over the period 1989 to 2001, $(T=13)$ for imports and 1989 to 2000, $(T=12)$ for exports from the UK, Germany, France, Italy, Netherlands and Spain, and the span of countries is based on data availability. At its maximum we have a cross section of 22 industries and 6 countries, $(\mathrm{N}=132)$. Our study is slightly more focused than studies which cover a much greater span of countries. ${ }^{9}$ This is out of necessity given the detailed disaggregate data series that we are considering here. Also the use of disaggregate deflators encourages us to adopt the Armington approach, in contrast to other strands of the literature which abstracts from different deflators and adopts a Gravity approach.

We obtain the volume of trade by deflating the value of imports, or exports, for our sectors by our sectoral price proxy, the value added deflator. Our annual measure of exchange rate volatility $(V O L)$ is the standard deviation of the log first difference of bilateral US Dollar monthly exchange rate (from IMF, International Financial Statistics). We also consider the impact of the annual real oil price volatility, (VOIL), based on the first difference of monthly West Texas Intermediate deflated by the US consumer price deflator. Table 2 provides summary statistics of the data. Most US imports, based on our classification, are in differentiated goods (i.e. around three quarters). In terms of exchange rate volatility, the continental European countries exhibit marginally greater bilateral Dollar volatility than the UK in our sample period. We also incorporate an exchange rate misalignment term, which may be important in this context, and we capture this in terms of deviations from purchasing power parity (PPP). Clearly, given the evident slow mean reversion speeds of real exchange rates, trying to capture exchange rate misalignment using PPP is likely to be contentious. However, given that there is no universal agreement in the profession about the

\footnotetext{
${ }^{8}$ US imports are mainly (around 88\%) priced in US Dollars, Tavlas (1997). Price changes from suppliers will have an immediate impact on import prices.

${ }^{9}$ For example, Rose (2000) considers 186 diverse countries at the aggregate level.
} 
most appropriate way of defining an equilibrium exchange rate, and given our main focus is on exchange rate volatility, we believe our misalignment measure is not unreasonable. ${ }^{10}$

\section{Results}

Our estimation approach is based on the following determinants of the volume of trade:

$$
\ln Z_{i j t}=f\left(\ln Y_{i . t}, R P_{i j t}, V O L_{. j t}, M P P P_{. j t}, V O I L_{. t}\right),
$$

where $Z_{i j t}$ is the value of US trade for industry $i$ (either imports, $M$, or exports, $X$ ) from country $j$, deflated by the sectoral value added deflator $P_{i j t}, Y_{i . t}$ is the sectoral value added in US industry $i, R P_{i j t}$ is the relative price between country $j$ and the US for industry $i, V O L_{. j t}$ is bilateral US Dollar exchange rate volatility against country $j, M P P P_{. j t}$ is the misalignment term based on deviations from purchasing power parity of the Dollar against currency $j$, and $V O I L_{. . t}$ is the volatility of the oil price. Estimation is based on static fixedeffects. The results presented here are derived using a simple instrumental variables method where we take the fitted values from an $A R(n)$ of exchange rate volatility itself ( $n$ is determined by an Information Criteria). We believe that the instruments will primarily control for measurement error. Since the US did not have formal or informal exchange rate arrangements with European countries in the 1990s, there is unlikely to be the kind of endogeneity issues encountered by Tenreyro (2004). ${ }^{11}$ Our sectoral disaggregations, are based on networks (when we separate industries into differentiated or homogeneous groupings) and we use a Hausman test suggested by Pesaran, Smith and Im (1996) to confirm whether our choice of pooled sectors is appropriate.

[Table 3 Here]

\subsection{Total Goods Trade}

Our first set of results for the impact of exchange rate volatility on sectoral trade are presented in Table 3, where we consider the impact on all industries combined in a single panel. Note, first, the demand and relative price terms are significant and reasonably signed. They are approximately equivalent for both imports and export groupings. Exchange rate volatility proves to be strongly significant and has a negative effect on both imports and exports, although the impact is almost a third larger in estimated sign and

\footnotetext{
${ }^{10}$ Indeed there may be greater evidence of purchasing power parity at the disaggregate level, see Crucini and Shintani (2004) and Imbs et al. (2005).

${ }^{11}$ For example Tenreyro (2004) does find that instrumental variables can be influential, but she has a much larger number of countries in her study of aggregate data, whilst we approach the question using sectoral data.
} 
marginally more significant in the export equations. The estimated coefficient on the exchange rate misalignment term is positively signed, as expected, for both imports and exports. A depreciation of the exporting country's currency greater than that suggested by PPP will have a positive and significant effect on trade. There does not appear to be an important role for oil price volatility in this specification. A Hausman test, based on equivalence of the fixed-effects and a random coefficients estimator, provides evidence that we can not pool all cross sections at once, which is suggestive that we should be working with disaggregate sectors.

[Table 4 Here]

Although our estimated specification is written for bilateral trade, there are likely to be important third country effects which will impact on our bilateral trade levels. For example, Clark et al. (2004) emphasise that an analysis of the effects of volatility on trade using fixed-effects estimation does not fully take account of the problem of "multilateral resistance" as introduced by Anderson and van Wincoop (2003). In particular, fixed-effects will only account for third country effects to the extent they are constant, but they will not account for variation in these effects. Since for example, tariffs may change between the countries under examination, and for countries not included in our study, this could consequently influence the level of bilateral trade under study. Clark et al. (2004) suggest that trade equations can be made robust to such "multilateral resistance" by incorporating time effects into the analysis. When the authors do this they generally find less, or no, evidence of an effect from exchange rate volatility on trade. ${ }^{12}$ We consequently cross sectionally demean our data to take account of time effects. Additionally, such period idiosyncrasies could be important in representing global business cycles and shocks. Taking account of time effects is also important for econometric reasons, since our estimation approach assumes the residuals are cross sectionally independent and it is not possible to implement a SUR analysis given the dimensions of our panel $(\mathrm{N}>\mathrm{T})$.

Table 4 presents the results for all industries taking account of cross section and period effects. Both the size of output and relative price elasticities are reduced slightly in both import and export equations. Interestingly, the effect of volatility on import trade disappears (although it remains negative in sign and the t-statistic is around one). For exports there is an effect from exchange rate volatility which is approximately

\footnotetext{
${ }^{12}$ Clark et al. (2004) acknowledge that including cross section and time dummies may overcorrect for the problem of "multilateral resistance" and that the forces underlying bilateral exchange rate volatility are time and cross section specific. Clark et al. (2004) go somewhat further and include time-varying fixed effects. How appropriate such an approach is may be open to question since
} 
the same size as before and is still significant at the $1 \%$ level. This suggests that because exports are more proximate to the decisions of the firm, they may be more responsive to volatility. Imports on the other hand include cost, insurance and freight which may be unresponsive to volatility. The misalignment term is not significant with the demeaned data. There is some evidence from a Hausman test that we can pool estimated coefficients across cross-sections. However, the Hausman test for the most interesting and relevant specification (i) for exports, indicates that we can not pool all 22 industries together, which suggests that we should pursue a further disaggregation of our cross sections. ${ }^{13}$

\subsection{Differentiated Goods Trade}

Although we assume that there are equivalent coefficients across cross sections, this is not always born out by the evidence. Rauch (1999) has often been invoked to suggest that exchange rate volatility (which is one particular type of transaction cost for trade) may have a larger effect on differentiated goods trade. Table 5 reports results for differentiated goods trade and suggests that output and relative prices are again important for both imports and exports. The size of the estimated relative price coefficient for differentiated goods trade is slightly less than for total trade, which would lead us to believe that differentiated goods trade is less sensitive to relative prices, consistent with the search costs involved in differentiated goods trade, as emphasized by Rauch (1999). There is an important role for the misalignment terms in these specifications but not for oil price volatility. However, results from the Hausman test do not suggest that we can pool these sectors.

We also go on to consider the importance of time effects by cross sectionally demeaning the data. From Table 6, we do not find an important role for exchange rate volatility on imports. We find evidence of volatility effecting exports (replicating the results for total export trade although the size

[Table 5 Here]

[Table 6 Here]

\footnotetext{
it will be intensive in terms of degrees of freedom, could potentially increase the size of estimated coefficient standard errors and counteract many of the efficiency benefits of panel estimation.

${ }^{13}$ We note that in panels there may be less of a problem with spurious regression issues due to cross sectional averaging using fixed-effects, see Phillips and Moon (1999). Preliminary evidence based on Pedroni's (1999) panel cointegration tests were consistent with this perspective.
} 
of the coefficient is slightly larger). The effect of the misalignment term again becomes insignificant in the presence of time effects irrespective of whether we consider imports or exports. Of course a general deviation of the dollar from equilibrium may be being modelled by the time effects. There is no role for oil price volatility, suggesting our results are insensitive to including this factor. The Hausman test (based on equivalence of fixed effects and a random coefficients model) indicates that we can pool the cross sections in this situation which suggests we now have an appropriate level of disaggregation.

\subsection{Random Effects Estimation}

As a robustness check we consider (two way) random-effects estimation. Random-effects estimation, unlike fixed-effects, assumes regressors and unobserved factors are uncorrelated. If fixed-effects and random-effects estimation is different, this suggests there is a correlation. A Hausman approach, different from the earlier test of parameter heterogeneity, can be used to examine the equivalence of fixed and random-effects estimation and hence whether unobserved factors are correlated with the regressors, see Hsiao (2003). This can shed light on the suggestion by Clark et al. (2004) that volatility effects disappear in the presence of time dummies, since they model volatility's period specific nature.

\section{[Table 7 Here]}

In Table 7 using random-effects estimation we find that differentiated and total exports trade remains negatively affected by exchange rate volatility. ${ }^{14}$ However, the Hausman test for differentiated goods trade rejects random-effects estimation, supporting our earlier use of fixed-effects. Additionally this provides evidence supporting Clark's et al. (2004) point that unobserved factors may be correlated with volatility and partly explains why they do not find an impact on trade. Homogeneous goods exports are unresponsive to exchange rate volatility using random effects estimation, consistent with Rauch's (1999) suggestion, and emphasising the importance of finding appropriate groupings.

\footnotetext{
${ }^{14}$ The estimated coefficient on the impact of exchange rate volatility on homogeneous goods exports is more than two standard errors greater than the estimated coefficient on differentiated exports, which indicates that these two groupings are significantly different. This is consistent with the evidence from the Hausman Poolability tests which indicated that we have appropriately grouped sectors.
} 


\section{Conclusion}

In this paper we have considered the impact of exchange rate uncertainty on sectoral bilateral imports and exports to the US from a sample of six European countries. The main novelties over other work in this area, for example Clark et al. (2004), lies in our use of disaggregate price data as our trade deflator, rather than the US consumer price index, and our construction of new disaggregate sectors to examine the importance of exchange rate uncertainty. The use of a deflator such as the US CPI may result in the imposition of inappropriate constraints, which affect subsequent results and may explain why exchange rate volatility often appears as an insignificant explanatory variable in trade equations. Also our use of detailed sectoral deflators emphasizes the pertinence of an Armington specification. Our construction of the disaggregate sectors is based upon economic and econometric considerations and we find Rauch's (1999) discussion on the different effect of networks on trade pertinent here. To recap, for goods which trade only where there are costly networks in place, any factor which reduces the revenue of such trade will have a direct bearing on the firm's profitability. For goods sold on organised exchanges it is much easier to find alternative buyers when market conditions change and where exchange rates move against a firm's decision to engage in international trade, it should be possible to switch markets. In the latter situation exchange rate volatility should not adversely affect trade.

Amongst our findings is the result that pooling all industries together provides us with evidence of a negative effect on trade from exchange rate volatility. But using econometric criteria in particular we find evidence that this effect may be different across industries, as suggested most recently by the empirical study of Peridy (2003), although he abstracts from relative price effects. We also find that output and relative price coefficients are different on a disaggregated basis. Moreover, the effect of exchange rate uncertainty is negative and significant for differentiated goods, which is the great majority of trade, and insignificant for homogeneous goods, supporting the arguments of Rauch (1999). This would seem to suggest that sectoral differences do exist in explaining the different impact of volatility on trade and may be based on the characteristics of the markets in which they trade. We believe this is an important finding and may be the key to understanding why so many studies have not found a clear-cut empirical relationship between exchange rate volatility and trade when using aggregate trade data. It also suggests that a greater degree of disaggregation, at the industry, product or firm level, may provide further worthwhile results. 


\section{References}

Anderson, J.E., van Wincoop, E., 2003. Gravity with gravitas: A solution to the border puzzle. American Economic Review 93, 170-192.

Armington, P., 1969. A theory of demand for products distinguished by place of production. IMF Staff Papers 16, 170-201.

Baum, C., Caglayan, M., Ozkan, N., 2004. Nonlinear effects of exchange rate volatility on the volume of bilateral exports. Journal of Applied Econometrics 19, 1-23.

Belanger, D., Gutierrez, S., Racette, D., Raynauld, J., 1992. The impact of exchange rate variability on trade flows: Further results from sectoral US imports from Canada. North American Journal of Economics and Finance 3, 888-92.

Bini-Smaghi, L., 1991. Exchange rate variability and trade: Why is it so difficult to find any relationship? Applied Economics 23, 927-36.

Broda, C., Romalis, J., 2004. Identifying the relationship between trade and exchange rate volatility. Mimeo, FRBNY, Chicago GCB and NBER. IFM Conference NBER, March.

http://www.nber.org/confer/2004/ifms04/broda.pdf

Clark, P., Tamirisia, N., Wei, S.-J., Sadikov, A., Zeng, L., 2004. Exchange rate volatility and trade flows - some new evidence. IMF Occasional Paper.

http://www.imf.org/external/np/res/exrate/2004/eng/051904.htm

Crucini, M.J., Shintani, M., 2004. Persistence in law-of-one-price deviations: Evidence from micro-data. Working Paper \#02-W22R, Vanderbilt University.

Dell'Ariccia, G., 1999. Exchange rate fluctuations and trade flows: Evidence from the European Union. IMF Staff Papers 46, 315-334.

Demers, M. 1991. Investment under uncertainty irreversibility and the arrival of information over time. Review of Economic Studies 58, 333-50.

Dominguez, K.M.E., Tesar, L.L., 2001. Exchange rate exposure. NBER Working Paper \#8453.

Erkel-Rousse, H., Mirza, D., 2002. Import price elasticities: reconsidering the evidence. Canadian Journal of Economics 35, 282-306.

Ethier, W., 1973. International trade and the foreign exchange market. American Economic Review 63, 494-503.

Frankel, J., Wei, S.-J., 1993. Trade blocs and currency blocs. NBER Working Paper \#4335.

Hau, H., 2002. Real exchange rate volatility and economic openness: Theory and evidence. Journal of Money Credit and Banking 34, 611-630.

Head, K., Mayer, T., 2000. Non-Europe: The magnitude and causes of market fragmentation. Weltwirtschaftliches Archiv 136, 284-314.

Hooper, P., Kohlhagen, S., 1978. The effects of exchange rate uncertainty on the prices and volumes of international trade. Journal of International Economics 8, 483-511. 
Hsiao, C., 2003. Analysis of Panel Data. $2^{\text {nd }}$ Edition. Cambridge University Press: Cambridge.

Imbs, J., Mumtaz, H., Ravn, M.O. and Rey, H., 2005. PPP strikes back: Aggregation and the real exchange rate. Quarterly Journal of Economics 120, 1-43.

Klein, M.W., 1990. Sectoral effects of exchange rate volatility on US exports. Journal of International Money and Finance 9, 299-308.

Klein, M.W., Shambaugh, J.C., 2004. Fixed exchange rates and trade. NBER Working Paper \#10696.

McKenzie, M.D., 1999. The impact of exchange rate volatility on international trade flows. Journal of Economic Surveys 13, 71-106.

National Statistics, 2004. Industrial Disaggregation.

http://www.statistics.gov.uk/downloads/theme other/GSSMethodology No 15 v3.pdf

Pagan, A., 1984. Econometric issues in the analysis of regressions with generated regressions. International Economic Review 25, 221-247.

Pedroni, P., 1999. Critical values for cointegration tests in heterogeneous panels with multiple regressors. Oxford Bulletin of Economics and Statistics 61, 653-670.

Peridy, N., 2003. Exchange rate volatility, sectoral trade and aggregation. Weltwirtschaftliches Archiv 139, 389-418.

Pesaran, M.H., Smith, R.P., 1995. Estimating long-run relationships from dynamic heterogeneous panels. Journal of Econometrics 68, 79-113.

Pesaran, M.H., Smith, R.P., Im, K.S., 1996. Dynamic linear models for heterogeneous panels. In: Mátyás, L., P. Sevestre, (Eds.), The Econometrics of Panel Data, $2^{\text {nd }}$ Edition. Dordrect, Kluwer, pp. 145-195.

Phillips, P.C.B., Moon, H.R., 1999. Linear regression limit theory for nonstationary panel data. Econometrica 67, 1057-1112.

Rauch, J.R., 1999. Networks versus markets in international trade. Journal of International Economics 48, 7-37.

Rose, A., 2000. One Money, One Market: The effects of common currencies on trade. Economic Policy 30, 7-33.

Saito, M., 2004. Armington elasticities in intermediate inputs trade: A problem in using multilateral trade data. Canadian Journal of Economics 37, 1097-1117.

Savvides, A., 1992. Unanticipated exchange rate volatility and international trade. Weltwirtshaftliches Archiv 128, 446-463.

Shiells, C.R., Stern, R.M., Deardorff, A.V., 1986. Estimates of the elasticity of substitution between imports and home goods for the United States. Weltwirtschaftliches Archiv 122, 497-519.

Tavlas, G., 1997. The international use of the dollar: An optimal currency area perspective. World Economy 20, 709747.

Tenreyro, S., 2004. On the trade impact of nominal exchange rate volatility. Working Paper 03-2 Federal Reserve Bank of Boston www.bos.frb.org/economic/wp/wp2003/wp032.pdf 
de Vita, G., Abbott, A., 2004. The impact of exchange rate volatility on UK exports to EU countries. Scottish Journal of Political Economy 51, 62-81.

Wei, S.-J., 1999. Currency hedging and goods trade. European Economic Review 43, 1371-1394. 


\title{
Data Appendix
}

\section{Trade Data}

The Hamburg Institute of International Economics (HWWA) World Matrix of Sectoral Economic Data (http://www.hwwa.de/wmatrix) provides bilateral trade data for OECD countries on a sectoral basis over the period 1989-2001. Imports and exports are broken down by commodities and by partner countries. Values are expressed in thousands of United States Dollars and relate to declared transaction values (imports c.i.f., exports f.o.b.). The exchange rates from national currencies into United States dollars are taken from United Nations' Statistics Division, UNSD. The core data in the World Matrix come from the OECD's International Trade by Commodities Statistics (ITCS) and the UN's Commodity Trade Statistics (COMTRADE). The disaggregation by industries and product groups follows the Standard International Trade Classification (SITC).

A major advantage in taking the data from the World Matrix is that HWWA have applied the necessary conversion key to produce data by International Standard Industrial Classification (ISIC). This makes it possible to relate foreign and domestic data on a common statistical basis (domestic data, including sector/industry specific value added and value added deflators are conventionally provided by ISIC).

The conversion key is taken from Eurostat's classification server. World Matrix data has been aggregated from the 312 product groups at 3 digit SITC Rev.3, to the 27 industries at ISIC Rev.3 2 digit level (and partly 3 and 4 digit level). [The full correspondence table, 5 digit SITC Rev.3 (= 3069 product groups) to 4 digit ISIC Rev.3 (=127 industries) is available at Eurostat's classification server at http://europa.eu.int/comm/eurostat/ramon/. We used a version of this and aggregated up to a 3 digit SITC and 2 digit ISIC converter.]

\section{Value Added and Value Added Deflators:}

Sector specific deflators available from the Groningen Growth and Development Centre 60-Industry Database at http://www.ggdc.net. This provides internationally comparable data for OECD countries based on the 2-digit ISIC classification. Both value added and value added deflators are available for the period 1979-2001.

\author{
[Table A1 Here]
}


Table 1

Relevant trade and exchange rate volatility studies

\begin{tabular}{|c|c|c|c|c|c|c|c|c|c|c|}
\hline \multirow[t]{2}{*}{ Authors } & \multirow[t]{2}{*}{ Approach } & \multicolumn{4}{|c|}{ Data } & \multicolumn{3}{|c|}{ Conditioning Variables } & \multirow[t]{2}{*}{ Estimation } & \multirow[t]{2}{*}{ Key results } \\
\hline & & Source & $\begin{array}{l}\text { Level of aggregation } \\
\text { (i) }\end{array}$ & $\begin{array}{l}\text { Countries } \\
\text { (j) }\end{array}$ & $\begin{array}{l}\text { Time } \\
\text { (t) }\end{array}$ & Deflator & Demand & Volatility & & \\
\hline Klein (1990) & Armington & $\begin{array}{l}\text { Bureau of } \\
\text { Census } \\
\text { SITC }\end{array}$ & $\begin{array}{l}\text { Sectoral } \\
9 \text { sectors }\end{array}$ & $\begin{array}{l}\text { Bilateral } \\
7 \text { country }\end{array}$ & $\begin{array}{l}\text { 1978M2- } \\
\text { 1986M6 } \\
\text { Monthly }\end{array}$ & None & $\begin{array}{l}\text { Industrial } \\
\text { Prodtn. }\end{array}$ & $\begin{array}{l}\mathrm{SD}(\Delta \ln \\
\left.\left(\mathrm{P} / \mathrm{SP}^{*}\right)_{\mathrm{t}}\right) \\
\mathrm{t}=1, \ldots, 12\end{array}$ & SURE & $\begin{array}{l}5 / 9 \text { sectors affected } \\
\text { positively by volatility. } \\
\text { Risk neutral exporters. }\end{array}$ \\
\hline $\begin{array}{l}\text { Belanger et } \\
\text { al. (1992) }\end{array}$ & Armington & $\begin{array}{l}\text { Bureau of } \\
\text { Census }\end{array}$ & $\begin{array}{l}\text { Sectoral } \\
5 \text { sectors }\end{array}$ & $\begin{array}{l}\text { Bilateral } \\
\text { US-Can }\end{array}$ & $\begin{array}{l}\text { 1974Q1- } \\
\text { 1987Q3 } \\
\text { Quarterly }\end{array}$ & Unit Values & $\begin{array}{l}\text { Sectoral } \\
\text { Industrial } \\
\text { Prodtn. }\end{array}$ & $\begin{array}{l}\text { Forecast error } \\
\text { of forward } \\
\text { market }\end{array}$ & IVE/GIVE & No significant effect \\
\hline $\begin{array}{l}\text { Dell'Aricca } \\
\text { (1999) }\end{array}$ & Gravity & OECD & Aggregate & $\begin{array}{l}\text { Bilateral } \\
16 \text { European } \\
\text { Countries }\end{array}$ & $1975-1994$ & $\begin{array}{l}\text { Aggregate } \\
\text { Unit Values }\end{array}$ & GDP & $\begin{array}{l}\mathrm{SD}\left(\Delta \ln \mathrm{S}_{\mathrm{t}}\right) \\
\mathrm{t}=1, \ldots, 12 \\
\text { Forward error } \\
\text { Max and min }\end{array}$ & $\begin{array}{l}\text { IV/Pooled } \\
\text { Fixed } \\
\text { Effects }\end{array}$ & $\begin{array}{l}\text { Controlling for } \\
\text { simultaneity, negative } \\
\text { correlation exists trade } \\
\text { and volatility, }\end{array}$ \\
\hline Rose (2000) & Gravity & $\mathrm{UN}$ & Aggregate & $\begin{array}{l}\text { Bilateral } \\
186 \text { countries }\end{array}$ & $\begin{array}{l}1970-1990 \\
5 \text { yearly }\end{array}$ & $\begin{array}{l}\text { US GDP } \\
\text { Deflator }\end{array}$ & GDP & $\begin{array}{l}\mathrm{SD}\left(\Delta \ln \mathrm{l}_{\mathrm{t}}\right) \\
\mathrm{t}=1, \ldots, 60\end{array}$ & $\begin{array}{l}\text { Fixed } \\
\text { Effects }\end{array}$ & $\begin{array}{l}\text { Volatility }+1 \text { SD } \\
\Rightarrow>\text { Trade falls } 13 \%\end{array}$ \\
\hline Peridy (2003) & Armington & OECD ITCS & $\begin{array}{l}\text { Sectoral } \\
20 \text { sectors }\end{array}$ & $\begin{array}{l}\text { Multilateral } \\
\text { G7. Each to } \\
21 \text { countries }\end{array}$ & $\begin{array}{l}\text { 1975-2000 } \\
\text { Annual }\end{array}$ & $\begin{array}{l}\text { Supply } \\
\text { Variables } \\
\text { and Foreign } \\
\text { Production } \\
\text { Prices }\end{array}$ & GDP & $\begin{array}{l}\mathrm{SD}\left(\Delta \ln \mathrm{S}_{\mathrm{t}}\right) \\
\mathrm{t}=1, \ldots, 12 \\
\mathrm{GARCH} \\
\Sigma \mathrm{t}=1 . .12 \\
\text { monthly }\end{array}$ & $\begin{array}{l}\text { First } \\
\text { difference } \\
\text { OLS, } \\
\text { GMM }\end{array}$ & $\begin{array}{l}\text { Negative effect but not } \\
\text { consistently significant. } \\
\text { Different effect across } \\
\text { sectors }\end{array}$ \\
\hline $\begin{array}{l}\text { De Vita and } \\
\text { Abbott (2004) }\end{array}$ & Armington & $\begin{array}{l}\text { UK National } \\
\text { Statistics }\end{array}$ & $\begin{array}{l}\text { Sectoral } \\
4 \text { sectors }\end{array}$ & $\begin{array}{l}\text { Multilateral } \\
\text { UK exports to } \\
\text { EU14 }\end{array}$ & $\begin{array}{l}\text { 1993M1- } \\
\text { 2001M6 } \\
\text { Monthly }\end{array}$ & $\begin{array}{l}\text { Multilateral } \\
\text { Sectoral } \\
\text { Export Price }\end{array}$ & $\begin{array}{l}\text { Industrial } \\
\text { Prodtn. }\end{array}$ & $\begin{array}{l}\mathrm{SD}\left(\Delta \ln \mathrm{S}_{\mathrm{t}}\right) \\
\mathrm{t}=1, \ldots, 12 \\
\mathrm{SD}\left(\operatorname{lnS}_{\mathrm{t}}\right) \\
\mathrm{t}=1, \ldots, 12\end{array}$ & ARDL & $\begin{array}{l}\text { Long run volatility has } \\
\text { an effect on trade }\end{array}$ \\
\hline $\begin{array}{l}\text { Broda and } \\
\text { Romalis } \\
(2004)\end{array}$ & $\begin{array}{l}\text { Armington/ } \\
\text { Gravity }\end{array}$ & $\begin{array}{l}\text { Rauch (1999) } \\
\text { SITC Rev } 2\end{array}$ & $\begin{array}{l}\text { Sectoral } \\
\text { Raunch (1999) type: } \\
\text { Includes Differentiated }\end{array}$ & $\begin{array}{l}\text { Bilateral } \\
\text { Exports } \\
\text { Multi-country } \\
\text { study. }\end{array}$ & $\begin{array}{l}\text { 1970-1997 } \\
\text { Annual }\end{array}$ & $\begin{array}{l}\text { Unit Export } \\
\text { Prices }\end{array}$ & $\begin{array}{l}\text { GDP, } \\
\text { GDP*, per } \\
\text { capita, } \\
\text { GDP x } \\
\text { GDP* }\end{array}$ & $\begin{array}{l}\mathrm{SD}\left(\Delta \ln \mathrm{S}_{\mathrm{t}}\right) \\
\mathrm{t}=1, \ldots, 60 \\
\mathrm{~S}_{\mathrm{t}} \text { Hodrick- } \\
\text { Prescott }\end{array}$ & $\begin{array}{l}\text { OLS/ } \\
\text { GMM }\end{array}$ & $\begin{array}{l}\text { If volatility doubles } \\
=>\text { trade falls } 2 \%: \\
\text { Increase in trade } \\
=>12 \% \text { fall volatility }\end{array}$ \\
\hline $\begin{array}{l}\text { Clark et al. } \\
\text { (2004) }\end{array}$ & Gravity & $\begin{array}{l}\text { COMTRADE } \\
\text { SITC Rev } 1\end{array}$ & $\begin{array}{l}\text { Sectoral } \\
\text { Raunch (1999) type: } \\
\text { Includes Differentiated: } \\
98 \text { sectors }\end{array}$ & $\begin{array}{l}\text { Bilateral } \\
39 \text { countries }\end{array}$ & $\begin{array}{l}1975-2000 \\
5 \text { yearly }\end{array}$ & US CPI & GDP & $\begin{array}{l}\mathrm{SD}(\Delta \ln \\
\left.\left(\mathrm{P} / \mathrm{SP}^{*}\right)_{\mathrm{t}}\right) \\
\mathrm{t}=1, \ldots, 12\end{array}$ & $\begin{array}{l}\text { Fixed and } \\
\text { Time } \\
\text { Effects }\end{array}$ & $\begin{array}{l}+1 \text { SD } \\
\Rightarrow>\text { Trade falls } 7-9 \% \\
\text { But less impact with } \\
\text { time effects. }\end{array}$ \\
\hline $\begin{array}{l}\text { Tenreyro } \\
\text { (2004) }\end{array}$ & Gravity & $\begin{array}{l}\text { Feenstra et al. } \\
\text { (1997) }\end{array}$ & Aggregate & $\begin{array}{l}\text { Bilateral } \\
104 \text { countries }\end{array}$ & $\begin{array}{l}\text { 1970-1997 } \\
\text { Annual }\end{array}$ & US CPI & Gravity & $\begin{array}{l}\mathrm{SD}\left(\Delta \ln \mathrm{S}_{\mathrm{t}}\right) \\
\mathrm{t}=1, \ldots, 12 \\
\ln \mathrm{S}_{\mathrm{t}}-\ln \mathrm{S}_{\mathrm{t}-1}\end{array}$ & $\begin{array}{l}\text { OLS and } \\
\text { IV }\end{array}$ & $\begin{array}{l}+1 \text { SD } \\
\Rightarrow \text { falls } 4-8 \% \text { : } \\
\text { zero if IV }\end{array}$ \\
\hline Saito (2004) & Armington & $\begin{array}{l}\text { OECD ITCS } \\
\text { SITC/ISIC }\end{array}$ & $\begin{array}{l}\text { Sectoral } \\
10 \text { sectors }\end{array}$ & $\begin{array}{l}\text { Bilateral } \\
14 \text { countries }\end{array}$ & $\begin{array}{l}\text { 1970-1997 } \\
\text { Annual }\end{array}$ & $\begin{array}{l}\text { OECD ISDB } \\
\text { Industrial } \\
\text { Unit Labour } \\
\text { costs }\end{array}$ & $\begin{array}{l}\text { Industry } \\
\text { Value } \\
\text { Added } \\
\text { minus } \\
\text { Exports } \\
\end{array}$ & No volatility & $\begin{array}{l}\text { FMOLS } \\
\text { /panel }\end{array}$ & $\begin{array}{l}\text { Bilateral trade data } \\
\text { suggests lower } \\
\text { elasticities than } \\
\text { multilateral data }\end{array}$ \\
\hline This study & Armington & $\begin{array}{l}\text { COMTRADE } \\
\text { HWWA } \\
\text { ISIC Rev } 3\end{array}$ & $\begin{array}{l}\text { Sectoral } \\
22 \text { sectors }\end{array}$ & $\begin{array}{l}\text { Bilateral } \\
6 \text { countries }\end{array}$ & $\begin{array}{l}\text { 1989-2001 } \\
\text { Annual }\end{array}$ & $\begin{array}{l}\text { Industrial } \\
\text { VA deflator }\end{array}$ & $\begin{array}{l}\text { Industrial } \\
\text { Value } \\
\text { Added }\end{array}$ & $\begin{array}{l}\mathrm{SD}\left(\Delta \ln \mathrm{S}_{\mathrm{t}}\right) \\
\mathrm{t}=1, \ldots, 12\end{array}$ & $\begin{array}{l}\text { Fixed and } \\
\text { Time } \\
\text { Effects }\end{array}$ & $\begin{array}{l}\text { Negative effects with } \\
\text { differentiated imports } \\
\text { and exports }\end{array}$ \\
\hline
\end{tabular}


Table 2

Data Summary

\begin{tabular}{|c|c|c|c|c|c|c|c|}
\hline & UK & Germany & France & Italy & Netherlands & Spain & Total \\
\hline $\begin{array}{l}\text { US Imports } \\
\text { US\$Bn (1995) }\end{array}$ & 21.6 & 35.2 & 16.1 & 14.1 & 8.2 & 3.7 & 98.9 \\
\hline $\begin{array}{l}\text { Differentiated } \\
\text { (1995) }\end{array}$ & 16.0 & 27.2 & 11.1 & 9.8 & 6.0 & 1.8 & $73 \%$ \\
\hline $\begin{array}{l}\text { Homogeneous } \\
\text { (1995) }\end{array}$ & 5.6 & 8.0 & 5.0 & 4.3 & 2.2 & 1.9 & $27 \%$ \\
\hline $\begin{array}{l}\text { Mean } V O L \\
\text { (min,max) }\end{array}$ & $\begin{array}{c}2.20 \\
(1.16,4.61)\end{array}$ & $\begin{array}{c}2.49 \\
(1.61,3.85)\end{array}$ & $\begin{array}{c}2.44 \\
(1.15,3.74)\end{array}$ & $\begin{array}{c}2.48 \\
(0.61,4.58)\end{array}$ & $\begin{array}{c}2.52 \\
(1.38,3.85)\end{array}$ & $\begin{array}{c}2.52 \\
(1.26,3.97)\end{array}$ & \\
\hline $\begin{array}{l}\text { Mean VOIL } \\
\text { (min,max) }\end{array}$ & & & & & & & $\begin{array}{c}6.99 \\
(4.21,15.79)\end{array}$ \\
\hline
\end{tabular}

Table 3

Trade of All Industries: Fixed Effects

\begin{tabular}{|c|c|c|c|c|c|c|}
\hline \multirow[b]{3}{*}{ Value Added $\left(Y_{i . t}\right)$} & \multicolumn{3}{|c|}{ Imports } & \multicolumn{3}{|c|}{ Exports } \\
\hline & (i) & (ii) & (iii) & (i) & (ii) & (iii) \\
\hline & $\begin{array}{c}1.065 \\
(45.996)\end{array}$ & $\begin{array}{c}0.999 \\
(39.835)\end{array}$ & $\begin{array}{c}1.064 \\
(45.940)\end{array}$ & $\begin{array}{c}1.057 \\
(37.547)\end{array}$ & $\begin{array}{c}0.988 \\
(32.675)\end{array}$ & $\begin{array}{c}1.058 \\
(37.560)\end{array}$ \\
\hline Relative Prices $\left(R P_{i j t}\right)$ & $\begin{array}{c}-1.436 \\
(-29.227)\end{array}$ & $\begin{array}{c}-1.162 \\
(-18.042)\end{array}$ & $\begin{array}{c}-1.431 \\
(-28.986)\end{array}$ & $\begin{array}{c}-1.327 \\
(-22.481)\end{array}$ & $\begin{array}{c}-1.064 \\
(-14.460)\end{array}$ & $\begin{array}{c}-1.332 \\
(-22.484)\end{array}$ \\
\hline Ex. Rate Vol. $\left(V O L_{. j t}\right)$ & $\begin{array}{c}-0.068 \\
(-5.207)\end{array}$ & $\begin{array}{c}-0.070 \\
(-5.403)\end{array}$ & $\begin{array}{c}-0.070 \\
(-5.268)\end{array}$ & $\begin{array}{c}-0.087 \\
(-6.140)\end{array}$ & $\begin{array}{c}-0.085 \\
(-6.035)\end{array}$ & $\begin{array}{c}-0.085 \\
(-5.829)\end{array}$ \\
\hline Misalignment $\left(M P P P_{. j t}\right)$ & & $\begin{array}{c}0.626 \\
(6.461)\end{array}$ & & & $\begin{array}{c}0.705 \\
(5.870)\end{array}$ & \\
\hline Oil Price Vol. $\left(V O I L_{. t}\right)$ & & & $\begin{array}{c}-0.003 \\
(-0.824)\end{array}$ & & & $\begin{array}{c}0.004 \\
(1.009)\end{array}$ \\
\hline $\begin{array}{l}\text { Hausman Statistic } \\
\text { [Homogeneity] }\end{array}$ & $\begin{array}{l}304.95 \\
{[0.000]}\end{array}$ & NA & $\begin{array}{l}202.18 \\
{[0.000]}\end{array}$ & $\begin{array}{c}36.66 \\
{[0.000]}\end{array}$ & $\begin{array}{c}65.64 \\
{[0.000]}\end{array}$ & $\begin{array}{l}518.56 \\
{[0.000]}\end{array}$ \\
\hline
\end{tabular}

Notes: Results are based on fixed-effects estimation (t-statistics in parentheses, significant at $5 \%$ level in bold). Hausman test has a joint null of cross sectional parameter homogeneity and is based on equivalence of coefficients of fixed-effects estimation and a random coefficients model [p-values in squared brackets]. All industrial sectors pooled (22 sectors) for six countries. Sectors included: Fish, Food, Textiles, Cloth, Leather, Wood, Pulp, Print and Publishing, Mineral Oil, Chemicals, Rubber, Non-Metallic Mineral Products, Basic Metals, Fabricated Metal, Mechanical Engineering, Office Machinery, Electrical Machinery, Radio and TV, Instruments, Motor Vehicles, Ships and Boats, Air and Space. 
Table 4

Trade of All Industries: Fixed and Time Effects

\begin{tabular}{|c|c|c|c|c|c|c|}
\hline & \multicolumn{3}{|c|}{ Imports } & \multicolumn{3}{|c|}{ Exports } \\
\hline & (i) & (ii) & (iii) & (i) & (ii) & (iii) \\
\hline Value Added $\left(Y_{i, t}\right)$ & $\begin{array}{c}0.958 \\
(38.712)\end{array}$ & $\begin{array}{c}0.962 \\
(38.566)\end{array}$ & $\begin{array}{c}0.958 \\
(38.700)\end{array}$ & $\begin{array}{c}0.932 \\
(31.330)\end{array}$ & $\begin{array}{c}0.931 \\
(31.057)\end{array}$ & $\begin{array}{c}0.932 \\
(31.319)\end{array}$ \\
\hline Relative Prices $\left(R P_{i j t}\right)$ & $\begin{array}{c}-1.125 \\
(-18.683)\end{array}$ & $\begin{array}{c}-1.150 \\
(-18.090)\end{array}$ & $\begin{array}{c}-1.125 \\
(18.677)\end{array}$ & $\begin{array}{c}-1.050 \\
(-15.381)\end{array}$ & $\begin{array}{c}-1.046 \\
(-14.496)\end{array}$ & $\begin{array}{c}-1.050 \\
(15.375)\end{array}$ \\
\hline Ex. Rate Vol. $\left(V O L_{. j t}\right)$ & $\begin{array}{l}-0.035 \\
(-1.252)\end{array}$ & $\begin{array}{l}-0.026 \\
(-.920)\end{array}$ & $\begin{array}{l}-0.035 \\
(1.252)\end{array}$ & $\begin{array}{c}-0.085 \\
(-2.743)\end{array}$ & $\begin{array}{c}-0.086 \\
(-2.736)\end{array}$ & $\begin{array}{l}-0.085 \\
(2.742)\end{array}$ \\
\hline Misalignment $\left(M P P P_{. j t}\right)$ & & $\begin{array}{c}-0.216 \\
(-1.214)\end{array}$ & & & $\begin{array}{c}0.040 \\
(0.200)\end{array}$ & \\
\hline Oil Price Vol. (VOIL..$t)$ & & & $\begin{array}{c}0.000 \\
(0.000)\end{array}$ & & & $\begin{array}{c}0.000 \\
(0.000)\end{array}$ \\
\hline $\begin{array}{l}\text { Hausman Statistic } \\
\text { [Homogeneity] }\end{array}$ & $\begin{array}{c}2.28 \\
{[0.516]}\end{array}$ & $\begin{array}{c}5.13 \\
{[0.274]}\end{array}$ & $\begin{array}{c}1.32 \\
{[0.859]}\end{array}$ & $\begin{array}{c}8.79 \\
{[0.032]}\end{array}$ & $\begin{array}{c}3.18 \\
{[0.528]}\end{array}$ & $\begin{array}{c}1.18 \\
{[0.881]}\end{array}$ \\
\hline
\end{tabular}

Notes: Based on fixed-effects estimation using cross sectionally demeaned data (t-statistics in parentheses, significant at $5 \%$ level in bold). Hausman test has a joint null of cross sectional parameter homogeneity and is based on equivalence of coefficients of fixed-effects estimation and a random coefficients model [p-values in squared brackets]. For sectors included see Table 3.

Table 5

Differentiated Goods Trade: Fixed Effects

\begin{tabular}{|c|c|c|c|c|c|c|}
\hline \multirow[b]{3}{*}{ Value Added $\left(Y_{i, t}\right)$} & \multicolumn{3}{|c|}{ Imports } & \multicolumn{3}{|c|}{ Exports } \\
\hline & (i) & (ii) & (iii) & (i) & (ii) & (iii) \\
\hline & $\begin{array}{c}1.076 \\
(39.424)\end{array}$ & $\begin{array}{c}0.985 \\
(32.480)\end{array}$ & $\begin{array}{c}1.075 \\
(39.393)\end{array}$ & $\begin{array}{c}1.062 \\
(33.517)\end{array}$ & $\begin{array}{c}1.000 \\
(28.597)\end{array}$ & $\begin{array}{c}1.062 \\
(33.508)\end{array}$ \\
\hline Relative Prices $\left(R P_{i j t}\right)$ & $\begin{array}{c}-1.359 \\
(-19.978)\end{array}$ & $\begin{array}{c}-0.973 \\
(-10.785)\end{array}$ & $\begin{array}{c}-1.347 \\
(-19.678)\end{array}$ & $\begin{array}{c}-1.280 \\
(-16.301)\end{array}$ & $\begin{array}{c}-1.025 \\
(-10.258)\end{array}$ & $\begin{array}{c}-1.285 \\
(-16.263)\end{array}$ \\
\hline Ex. Rate Vol. $\left(V O L_{. j t}\right)$ & $\begin{array}{c}-0.083 \\
(-4.397)\end{array}$ & $\begin{array}{c}-0.086 \\
(-4.616)\end{array}$ & $\begin{array}{c}-0.089 \\
(-4.601)\end{array}$ & $\begin{array}{c}-0.098 \\
(-4.992)\end{array}$ & $\begin{array}{c}-0.095 \\
(-4.924)\end{array}$ & $\begin{array}{c}-0.096 \\
(-4.791)\end{array}$ \\
\hline Misalignment $\left(M P P P_{. j t}\right)$ & & $\begin{array}{c}0.909 \\
(6.360)\end{array}$ & & & $\begin{array}{c}0.690 \\
(4.079)\end{array}$ & \\
\hline Oil Price Vol. $\left(V O I L_{. t}\right)$ & & & $\begin{array}{c}-0.007 \\
(-1.471)\end{array}$ & & & $\begin{array}{c}0.003 \\
(0.540)\end{array}$ \\
\hline $\begin{array}{l}\text { Hausman Statistic } \\
\text { [Homogeneity] }\end{array}$ & $\begin{array}{l}163.49 \\
{[0.000]}\end{array}$ & NA & $\begin{array}{c}10.60 \\
{[0.032]}\end{array}$ & $\begin{array}{c}19.20 \\
{[0.000]}\end{array}$ & $\begin{array}{c}41.95 \\
{[0.000]}\end{array}$ & $\begin{array}{c}44.33 \\
{[0.000]}\end{array}$ \\
\hline
\end{tabular}

Notes: Based on fixed-effects estimation (t-statistics in parentheses, significant at $5 \%$ level in bold). Hausman test statistic has a joint null of cross sectional parameter homogeneity and is based on equivalence of coefficients of fixed-effects estimation and a random coefficients model [p-values in squared brackets]. Differentiated goods trade (14 sectors) is Durable, Non-Durable and Investment goods and includes the following sectors: Fabricated Metal, Mechanical Engineering, Office Machinery, Electrical Machinery, Radio and TV, Instruments, Motor Vehicles, Ships and Boats, Air and Space, Fish, Food, Textiles, Cloth, Print and Publishing. 
Table 6

Differentiated Goods Trade: Fixed and Time Effects

\begin{tabular}{|c|c|c|c|c|c|c|}
\hline \multirow[b]{3}{*}{ Value Added $\left(Y_{i, t}\right)$} & \multicolumn{3}{|c|}{ Imports } & \multicolumn{3}{|c|}{ Exports } \\
\hline & (i) & (ii) & (iii) & (i) & (ii) & (iii) \\
\hline & $\begin{array}{c}0.939 \\
(31.416)\end{array}$ & $\begin{array}{c}0.939 \\
(31.006)\end{array}$ & $\begin{array}{c}0.939 \\
(31.403)\end{array}$ & $\begin{array}{c}0.945 \\
(27.329)\end{array}$ & $\begin{array}{c}0.940 \\
(26.870)\end{array}$ & $\begin{array}{c}0.945 \\
(27.314)\end{array}$ \\
\hline Relative Prices $\left(R P_{i j t}\right)$ & $\begin{array}{c}-0.929 \\
(-11.014)\end{array}$ & $\begin{array}{c}-0.923 \\
(-10.318)\end{array}$ & $\begin{array}{c}-0.929 \\
(11.009)\end{array}$ & $\begin{array}{c}-1.009 \\
(-10.819)\end{array}$ & $\begin{array}{c}-0.974 \\
(-9.836)\end{array}$ & $\begin{array}{c}-1.009 \\
(-10.813)\end{array}$ \\
\hline Ex. Rate Vol. $\left(V O L_{. j t}\right)$ & $\begin{array}{c}-0.032 \\
(-0.806)\end{array}$ & $\begin{array}{c}-0.034 \\
(-0.831)\end{array}$ & $\begin{array}{c}-0.032 \\
(-0.821)\end{array}$ & $\begin{array}{c}-0.111 \\
(-2.588)\end{array}$ & $\begin{array}{c}-0.118 \\
(-2.728)\end{array}$ & $\begin{array}{c}-0.111 \\
(-2.586)\end{array}$ \\
\hline Misalignment $\left(M P P P_{. j t}\right)$ & & $\begin{array}{c}0.052 \\
(0.204)\end{array}$ & & & $\begin{array}{c}0.292 \\
(1.064)\end{array}$ & \\
\hline Oil Price Vol. $\left(V O I L_{. t}\right)$ & & & $\begin{array}{c}-0.002 \\
(-0.350)\end{array}$ & & & $\begin{array}{c}0.000 \\
(0.000)\end{array}$ \\
\hline $\begin{array}{l}\text { Hausman Statistic } \\
\text { [Homogeneity] }\end{array}$ & $\begin{array}{c}0.66 \\
{[0.883]}\end{array}$ & $\begin{array}{c}2.92 \\
{[0.571]}\end{array}$ & NA & $\begin{array}{c}0.72 \\
{[0.868]}\end{array}$ & $\begin{array}{c}3.71 \\
{[0.446]}\end{array}$ & $\begin{array}{c}0.22 \\
{[0.994]}\end{array}$ \\
\hline
\end{tabular}

Table 7

Random Effects (Two Way) Estimation

\begin{tabular}{|c|c|c|c|c|c|c|}
\hline \multirow[b]{2}{*}{ Value Added $\left(Y_{i, t}\right)$} & \multicolumn{3}{|c|}{ Imports } & \multicolumn{3}{|c|}{ Exports } \\
\hline & $\begin{array}{c}\text { Total } \\
\mathbf{0 . 9 7 4} \\
(\mathbf{3 9 . 8 4 7 )}\end{array}$ & $\begin{array}{c}\text { Different. } \\
\text { 0.977 } \\
\text { (33.180) }\end{array}$ & $\begin{array}{c}\text { Homogen. } \\
\mathbf{0 . 3 9 9} \\
\mathbf{( 5 . 2 3 5 )}\end{array}$ & $\begin{array}{c}\text { Total } \\
\mathbf{0 . 9 4 6} \\
(\mathbf{3 2 . 4 7 1 )}\end{array}$ & $\begin{array}{c}\text { Different. } \\
\mathbf{0 . 9 8 1} \\
(\mathbf{2 9 . 0 3 6 )}\end{array}$ & $\begin{array}{c}\text { Homogen. } \\
\text { 0.366 } \\
\text { (3.516) }\end{array}$ \\
\hline Relative Prices $\left(R P_{i j t}\right)$ & $\begin{array}{c}-1.173 \\
(-18.541)\end{array}$ & $\begin{array}{c}-1.002 \\
(-11.323)\end{array}$ & $\begin{array}{c}-1.457 \\
(-21.190)\end{array}$ & $\begin{array}{c}-1.076 \\
(-15.026)\end{array}$ & $\begin{array}{c}-1.061 \\
(-10.862)\end{array}$ & $\begin{array}{c}-1.079 \\
(-11.221)\end{array}$ \\
\hline Ex. Rate Vol. $\left(V O L_{. j t}\right)$ & $\begin{array}{c}-0.028 \\
(-0.988)\end{array}$ & $\begin{array}{c}-0.036 \\
(-0.899)\end{array}$ & $\begin{array}{c}-0.012 \\
(-0.410)\end{array}$ & $\begin{array}{c}-0.086 \\
(-2.765)\end{array}$ & $\begin{array}{c}-0.118 \\
(-2.736)\end{array}$ & $\begin{array}{c}-0.037 \\
(-0.945)\end{array}$ \\
\hline Misalignment $\left(M P P P_{. j t}\right)$ & $\begin{array}{c}-0.268 \\
(-1.533)\end{array}$ & $\begin{array}{l}-0.126 \\
(-0.505)\end{array}$ & $\begin{array}{c}-0.487 \\
(-2.793)\end{array}$ & $\begin{array}{c}-0.045 \\
(-0.233)\end{array}$ & $\begin{array}{c}0.083 \\
(0.311)\end{array}$ & $\begin{array}{l}-0.253 \\
(-1.031)\end{array}$ \\
\hline Constant & $\begin{array}{c}2.130 \\
(6.445)\end{array}$ & $\begin{array}{c}2.052 \\
(5.060)\end{array}$ & $\begin{array}{c}8.222 \\
(\mathbf{9 . 8 7 8})\end{array}$ & $\begin{array}{c}2.558 \\
(6.857)\end{array}$ & $\begin{array}{c}2.254 \\
(5.114)\end{array}$ & $\begin{array}{c}8.530 \\
(7.597)\end{array}$ \\
\hline $\begin{array}{l}\text { Hausman Statistic } \\
\text { [Fixed vs. Random Effects] }\end{array}$ & $\begin{array}{c}8.39 \\
{[.078]}\end{array}$ & $\begin{array}{l}30.01 \\
{[.000]}\end{array}$ & $\begin{array}{c}1.89 \\
{[.756]}\end{array}$ & $\begin{array}{c}8.76 \\
{[0.068]}\end{array}$ & $\begin{array}{c}22.63 \\
{[0.000]}\end{array}$ & $\begin{array}{c}1.13 \\
{[0.89]}\end{array}$ \\
\hline
\end{tabular}

Notes: Based on random-effects estimation, (t-statistics in parentheses, significant at $5 \%$ level in bold). Hausman test is a test of equivalence of fixed-effects and random-effects [p-values in squared brackets]. Rejection of the null suggests fixed-effects is the appropriate method. All industrial sectors pooled ( 22 sectors) for six countries. For further details of sectors see Table A1. 


\section{Appendix}

Table A1

Industrial Classifications and Groupings

\begin{tabular}{|c|c|c|c|c|}
\hline \multirow[t]{2}{*}{ Industry } & \multirow[t]{2}{*}{ ISIC } & \multicolumn{2}{|c|}{ Differentiated } & \multirow{2}{*}{$\begin{array}{l}\text { Homogeneous/ } \\
\text { Intermediate }\end{array}$} \\
\hline & & D \& I & ND & \\
\hline Fishing & I05 & & $\mathrm{x}$ & \\
\hline Food, drink \& tobacco & I15-16 & & $\mathrm{x}$ & \\
\hline Textiles & $\mathrm{I} 17$ & & $\mathrm{x}$ & \\
\hline Clothing & $\mathrm{I} 18$ & & $\mathrm{x}$ & \\
\hline Leather and footwear & I19 & & & $\mathrm{x}$ \\
\hline Wood \& products of wood and cork & $\mathrm{I} 20$ & & & $\mathrm{x}$ \\
\hline Pulp, paper \& paper products & $\mathrm{I} 21$ & & & $\mathrm{x}$ \\
\hline Printing \& publishing & $\mathrm{I} 22$ & & $\mathrm{x}$ & \\
\hline Mineral oil refining, coke \& nuclear fuel & $\mathrm{I} 23$ & & & $\mathrm{x}$ \\
\hline Chemicals & $\mathrm{I} 24$ & & & $\mathrm{x}$ \\
\hline Rubber \& plastics & $\mathrm{I} 25$ & & & $\mathrm{x}$ \\
\hline Non-metallic mineral products & $\mathrm{I} 26$ & & & $\mathrm{x}$ \\
\hline Basic metals & $\mathrm{I} 27$ & & & $\mathrm{x}$ \\
\hline Fabricated metal products & $\mathrm{I} 28$ & $\mathrm{x}$ & & \\
\hline Mechanical engineering & I29 & $\mathrm{x}$ & & \\
\hline Office machinery & $\mathrm{I} 30$ & $\mathrm{x}$ & & \\
\hline Electrical machinery & I3 1 & $\mathrm{x}$ & & \\
\hline Radio, TV and communication & $\mathrm{I} 32$ & $\mathrm{x}$ & & \\
\hline Instruments & $\mathrm{I} 33$ & $\mathrm{x}$ & & \\
\hline Motor vehicles & $\mathrm{I} 34$ & $\mathrm{x}$ & & \\
\hline Building and repairing of ships and boats & $\mathrm{I} 351$ & $\mathrm{x}$ & & \\
\hline Aircraft and spacecraft & $\mathrm{I} 353$ & $\mathrm{x}$ & & \\
\hline
\end{tabular}

